\title{
HISTORICAL BACKGROUND OF ORIGIN AND FORMATION OF AN IMAGE CONCEPT IN SOCIAL AND HUMANITARIAN SCIENCES
}

\author{
Lubov Savva, D. in Education, Professor \\ Nikolay Saygushev, D. in Education, Professor \\ Olga Vedeneeva, Ph.D. in Education, Associate Professor
}

Elena Gasanenko, post-graduate student Nosov Magnitogorsk State Technical University - NMSTU, Magnitogorsk, Russia

\begin{abstract}
The paper presents the historical background of origin and formation of an image concept in social and humanitarian sciences. Historical stages of formation of a conceptual framework of the image are considered. Three main periods of the image concept are analyzed in details. Scientific approaches to the image concept at different historical stages are defined. The article highlights the circle of scientists who investigated the problem of the image-building. The basic categories and functions of the image concept reveal the history of the development of the image phenomenon. The authors also analyze the image concept from the viewpoint of various sciences such as philosophy, psychology, sociology, cultural studies, economy and management.
\end{abstract}

Keywords: historical prerequisites, historiography, historical stages, an image concept, conceptual framework of a problem, professional image, image-building, historical background, origin of the phenomenon, philosophy psychology.

Resumo: O artigo apresenta o contexto histórico da origem e formação de um conceito de imagem em ciências sociais e humanitários. As etapas históricas da formação de um quadro conceptual da imagem são considerados. Três períodos principais do conceito de imagem são analisados em detalhes. Abordagens científicas para o conceito de imagem em diferentes fases históricas são definidos. $\mathrm{O}$ artigo destaca o círculo de cientistas que investigaram o problema da construção da imagem. As categorias básicas e funções do conceito imagem revelar a história do desenvolvimento do fenômeno da imagem. Os autores também analisam o conceito de imagem do ponto 
de vista de várias ciências, tais como filosofia, psicologia, sociologia, estudos culturais, economia e gestão.

Palavras-chave: pré-requisitos históricos, historiografia, etapas históricas, um conceito de imagem, quadro conceptual de um problema, imagem profissional, construção de imagem, fundo histórico, origem do fenômeno, filosofia psicologia. 
The contemporary period of rapid economic development of Russia has led to a number of transformations in economic, political, cultural and social spheres of the Russian society. The country has entered a new era of humanization and considerable attention has been paid to the personality. Modern society has specified a strong necessity to reconsider main priorities of the personal development. A traditional approach to the society has been replaced with the new individual approach to each person. According to this approach anew system of the social presentation of the personality has been established. Nowadays great attention is paid to the problems of personal image characteristics and components (style, communication skills, a positive outlook, etc.). The urgency of an image concept studying is caused by the changes of the contemporary economic situation in the country when the presentation of the general appearance of the person is essential at the labor market.

Image as a concept category has appeared comparatively recently and often is considered only as the phenomenon of the 20th century. This is due to the fact that as an independent phenomenon image was considered within the framework of modernism and post-modernism culture. An image concept tis mostly understood as a tool of political activities which is used to influence public opinion but this approach does not reflect the true role of the image conceptin themodern society. However there is an enormous theoretical and practical material accumulated in the field of an image concept study. It should be mentioned that image asa sociocultural phenomenon appeared far before, than its scientific definition, therefore it is necessary to study the historical background of origin and formation of an image concept in social and humanitarian sciences.

In the history of an image conceptformation several periods can be distinguished: the first stage up to 1930th (preconceptual) includes the antiquity period, the Middle Ages and Renaissance. The second stage is time period beginning from 1920-30 to the 1970th, the third period these are the 1970th in the Western countries and the 1990th in Russia.

The first stage of an image conceptformation or so-called «preconceptual stage» is one of the longest; this period lasted up to 1930th. Having studied scientific sources of this period we came to the decision that the ideas concerning an image concept appeared in works of great number of scientists. What is more, some important aspects concerning image nature interpretation found reflection not only in scientific treatises, 
but also in fiction, memoirs and diaries of prominent figures of that time. It is supposed that the first prerequisites of an image conceptstudying appeared in the period of Antiquity.

Some structural components of the image were considered in scientific treatises of Socrates, Plato and Aristotle in spite of the fact that an image conceptwasn't a subject of their special attention. Scientific works of great philosophers of Antiquity were devoted to some fundamental philosophical categories as origin of a man, soul, society, state. These categories are in turn basic definitions of an image concept. Philosophers of the Middle Ages such as Thomas Aquinas, John Damascene, Peter Abelard, Bernard Klervossky, Boetsy, Erazmus Ciolek Witelo, Guguo Seong-Viktorsky, and others examined human nature according to the medieval world view. Essential questions of medieval scholasticism during this period were questions of interrelation between a body and a soul of a man, the social role of the person, ability of a person to form internal (spiritual) and external (corporal) image. In the literature of this period we can meet first references to the termimage. Scientists mentioned the termimago, in their research works dedicated to the process of sense perception which is described as penetration of an image of a thing through feelings. The process of sense perception was called visualization (visual image), researchers scrutinized necessary conditions for image creation, influence on the perception of the image.

Renaissance is the period of heightened interest in the person, to his corporal image. It is the era filled with sincere admiration of man's physical attraction and healthy sensuality. A lot of scientific papers of this period show a variety of approaches to the origin of a human nature, these approaches are important for understanding of an image concept in general. Thinkers, creators of Renaissance such as Leonardo da Vinci, Marsilio Fichino paid great attention to visualizations (vision, image).Perception through feelings occupied minds of great philosophers of that period.A special role of the first impression made by the person was admitted, a sharp split into images corporal and spiritual which arises in the presentation of the person was considered. It should be noted that an image concept is also considered as external and internal content of the person, an image which a person creates intentionally. It is possible to assume that Renaissance has given to the world new prerequisites to the origin of an image concept in the form as it is observed at present time. Interpretation of the person nature by the thinkers of Renaissance is close to modern concepts of image. 
In the literature of this period an image concept is often mentioned. The huge number of researches is devoted to the person. His physical shape and esthetic appeal of its image in general is considered. Renaissance isthe time of a new social order when the role of the person in the society becomes more powerful. Scientists of the Renaissance period realized the role the personal image which could bring to a social success of a person. The focus of the researches in the Renaissance period was on the person; his appearance and internal content were considered. It was obvious that external appeal plays huge role in the society. Public attention was drawn to practical advice concerning clothes, color, form or style.

Special attention should be paid to the works of agreat philosopher of Renaissance as Niccolo Machiavelli; in his works we can meet first notions of public opinion manipulation through image. It is known that image is created intentionally if the person doesn't possess personal qualities or natural appeal. Machiavelli created new components of an image concept such as realimage and required image. These categories of image are still basic.

New prerequisites of an image concepthave appeared in the period of Modern times. Scientists of that time carefully studied social order and social life forms. A number of scientific works dedicated indirectly to the image category through the analysis of the influence on the person appeared. Jean Jacques Rousseau a great philosopher,writer and composer of the 18th century, considered the problem of the personality. He created the theory of Natural Human and establishedStages of human development. Philosophers of that time didn't consider an image conceptas an independent phenomenon, the definition of image wasn't mentioned in works of that time yet.It should be noted that though scientists didn't study the phenomenon of image directly,they have revealed a number of aspects which are connected with the category of image in the researches of other areas of scientific knowledge.A number of researches directly connected with an image concept in its modern understanding appeared during this period of time as well as a definition of a public person. Though the definition of image didn't appear yet, the categories of image and stages of its formation were already considered by the scientists of Modern times. The stages of image-building are reflected in Hegel's works. A. Schopenhauer considered the nature of automatism of perception and paid attention to an important role of the first impression.Scientists, investigating human nature, drew attentionto basic categories, of 
image such as visions, image judgments and perception of an image. In the treatises scientists considered internal and external attributes of an image concept.

The second stage of a historiography of an image concept is the time period beginning in 1920-30. It is the time when basic representations of image concept appeared in sociology and psychology. These scientific spheres study individual and social behavior, the person in the society andsocial structure.

A number of fundamental theories connected with the essence of image phenomenonappeared at the second stage:«Maslow's hierarchy of needs»theory by A. Maslow. He pointed out the importance of focusing on the positive qualities in people, as opposed to treating them as a «bag of symptoms»[3].Psychoanalytical theory by $\mathrm{S}$. Freud is the theory of personality organization and the dynamics of personality development[5].Fundamental works by R. Linton such as «The Study of Man» and «The Tree of Culture».The theory of social roles is reflected in the works of such scientists as R. Linton, A. Inkels, D. Levinson, K. Hall, E. Tolmen. The school of behaviorism emerged in the early twentieth century led by John B. Watson. Behaviorists studied the human nature. Skinner, Bandura, and W. Mischel all proposed important behaviorist theories. Researchers believed that personality results from a two-way interaction between a person's characteristics and the environment. Bandura mentioned in his research work that people learn to respond in particular way by watching other people, who are called models.

Scientists of the second period continued to study interrelation between the person and the society. A number of scientific works of this period were devoted to such phenomena as social nature of the personality, adaptability, self-identification, stratification, status, status groups, and status privileges [4]. Researchers dedicated their works to a man, his personality, and his individual characteristics.

The definition of image appeared in the context of the research of such phenomena as social nature of the personality. It should be mentioned that in the works of the researchers of this period image was not considered as an independent concept yet, but the image conceptcould be found in various aspects of social and humanitarian knowledge of that time. The category of image was mentioned in the treatises of such researchersas E. Fromm, R. Brubeyker, M. Weber, P. Sorokin, T. Parsons. In their scientific works they considered image phenomenon from the standpoint of sociology and psychology. 
It is interesting to note that the authors of the second stage considered in such common categories as lighting, color, smell and their role in formation of a positive image from the scientific point of view. Some aspects of image concept were reflected in social, cultural and political fields of activity of the person of this period. Political advertising wasin widespread use at this stage, the use of image-building by politicians was a common feature of that time.Due to the social and political sphere of activity the image concept was considered as an independent scientific category.

The third period of the image concept development is the 1970th in Western countries and the 1990th in Russia. It is a stage of formation of the image concept as an independent scientific phenomenon in social and humanitarian sciences; it is connected with the semantic meaning ofthe image definition in foreign and Russian science. This period is noted by appearance of an independent scientific discipline an imageology, the scienceof creation the image. A noteworthy detail is that the problem of image-building was considered in Western countries much earlier than in Russia. Foreign approach to image studying is much different from Russian one. Owing to an applied orientation of image-buildingin Western countries, it has a great practical orientation.

At the beginning of the twentieth century the definition of image appeared in the USA, due to the urgent need in creation of a positive image of the political or public figure. The country the country went through a period of crisisand it led to a negative attitude to the USA in the world. Given situation had a negative impact on the attitude to the country at the international level. The term image was initially applied in the business sphere to promote goods and services in the consumer market. Public figures, commercial organizations of that time often consulted publicrelationsspecialists. With their help commercial initiatives moved ahead, politicians tried to obtain great success in the field of activity.

The study of methods of a positive image forming, image-building of a company, of a public figure or a common person ledtotheappearanceofanew applied scientific direction which was engaged in the study of the image phenomenon. Image forming process was regarded as an integral part ofa political or advertising campaign.

In Soviet Russia the phenomenon of image was considered extremely negative. The image concept was regarded as a trend of the western culture by means of which western authorities manipulated public opinion, managed mass consciousness. 
Anappreciation of the value of the image-building forming emerged in Russia only in the nineties when the country moved to a new stage of economic development.

Formation of the market transition in Russia entailed radical reorganizations of all state life. The problem of competitiveness in the country was highly complex. Goods of high quality from the West were freely offloaded onto Russian market and were extremely well received by the Russian consumers, whereas the Russian producer was not highly competitiveThis problem resulted in new requirements to goods of domestic producers. Therefore it was necessary to have adequate leverage on national consumer. Thus the image concept became popular among producers and was firmly established in the economic, political, social spheres of activity.

Image was not considered as an independent scientific and applied discipline over a long period of time. V.M. Shepel explains it with the fact that image was a subject matter first of all of political science, and thenit became a subject matter of political psychology and only after that image became relevant[8].In Russian literature image is considered as a scientific definition unlike in the western practical approach to this phenomenon. There are several scientific directions such as imageology, psychology of image, sociology of image, pedagogics of image where the category of imageis determined. Russianauthorssuch as A.Y.Panasyuk, T.E. Greenberg, D.V. Olshanskyused the image concept in their scientific works devoted to the phenomenon of political leadership for the first time.

V.M. Shepel was among the first developers of scientific-theoretical base of image studying. The scientist studiedthe structure of the image, its basic categories and methods of implementation in detail. Great influence on the development of the idea of image forming was exerted by the works of the researchers under the leadership of A.A. Bodalev. Modern scientists such as V.M. Shepel, E.A. Petrova, E.V. Zmanovskaya, and V.Salamatovcreate various techniques and programs which allow to createapositive image.

It is essential to observe the historical background of origin and formation of an image concept since it is a necessary condition for further studies of the image concept. There is a growing interest in the research of image forming, and it is possible to expect that the interest to this concept it will increase together with the further development of the society. The category of image is a subject matter of various fields of social and 


\section{CRIAR EDUCAÇÃO}

Revista do Programa de Pós-Graduação em Educação - UNESC

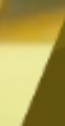

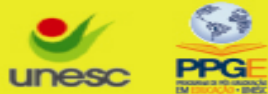

humanitarian sciences such as psychology, political science, management, sociology, philosophy of culture, pedagogics.

At present there is a range of some widespread interpretations of image category. First of all image is a communication factor. It is an intermediary between the person the possessing definite image and the person who perceives it in the course of social or professional communication. By means of image people successfully attain the set goals. Variability of interpretation of the image concept is due to its wide use in various areas of social and humanitarian knowledge that in turn makes the problem of choosing aprecise definition of this phenomenon extremely difficult.

In sociology image is understood as an external image which is created by the person to elicit a certain reaction from theperceiving person. Also image is considered as a set of certain properties based on general experience, traditions. In management, image is considered as a character, representation, perception by means of communication.From the point of view of psychology, image is a spontaneous phenomenon. Image reflects social expectations of certain groups therefore it can provide a person with success in different spheres of his life. 


\section{CRIAR EDUCAÇÃO \\ Revista do Programa de Pós-Graduação em Educação - UNESC}

\section{References:}

1. Derkach, A.A., Perelygina, E.B. Social and psychological concept of image. - M.: 2005. - 357c.[in Russian]

2. Feofanov, O.A. Advertizing: new technologies in Russia / O.A. Feofanov. - St. Petersburg, 2001. - 360 p. [in Russian]

3. Guseva, L.G. Ethnopedagogy and intercultural communication in higher education / Modern developmental psychology: main trends and prospects of research : materials of the international scientific conference on Oct. 20-21, 2015. - Prague :Vědeckovydavatelské centrum «Sociosféra-CZ», 2015. - 194 p. Pp.104108.http://sociosphera.com/files/conference/2015/k-10 20 15.pdf (accessed 02.09.2016)

4. Hoffman, Edward (1988). The Right to be Human: A Biography of Abraham Maslow. New York: St. Martin's Press.p. 109.

5. Paul, Robert A. (1991). Freud's anthropology. In James Neued. The Cambridge Companion to Freud. Cambridge: Cambridge University Press. p. 274.

6. Perelygina, E.B. Image as the phenomenon of intersubjective interaction: contents and ways of development: monograph / E.B. Perelygina, A.A. Derkach. - M.: International acmeological institute, 2003. - 635 p.[in Russian]

7. Petrova, E.A. Image and fortune of a person / E.A. Petrova. http://akme31 .narod.ru/18/html [in Russian]

8. Shepel, V.M. Imidzheologiya: Secrets of personal magnetism. M, 1997, 87 p.[in Russian]

9. Vasishcheva, A.V. Image: definition of the central concept of imidzheologiya / A.V. Vasishcheva, A.V. Nenasheva// Social and humanitarian knowledge. - 2005. - No. 4. - P. 311-317. [in Russian]

\section{Authors:}

Savva Lubov Ivanovna, Professor, Doctor in Education, Department of Pedagogy, NMSTU (Russia, Magnitogorsk, Lenin prospect, 38), savva.53@mail.ru.

Saygushev Nikolay Yakovlevish,Doctor in Education, Department of Pedagogy, NMSTU (Russia, Magnitogorsk, Lenin prospect, 38),nikolay74rus@mail.ru

Vedeneeva Olga Anatolievna,Ph.D. in Education, Associate Professor,Department of Pedagogy, NMSTU(Russia, Magnitogorsk,Lenin prospect, 38),vedeneeva12@mail.ru

Gasanenko Elena Alexandrovna, Post-graduate student, NMSTU(Russia, Magnitogorsk, Lenin prospect, 38), elenagasanenko@yandex.ru. 
